\title{
Discussion on Ways for Reform of Juris Master Training Mode of China*
}

\author{
Xuan Gao \\ Law School \& Intellectual Property School \\ Jinan University \\ Guangzhou, Guangdong, China 510632
}

\begin{abstract}
In practice, the education of juris master (JM) (law) in most colleges and universities in China is almost coped from the educational mode of Master of Laws (LLM), which makes the JM (law), a little awkward, and almost the same as the LLM. At the stage where law education and teaching are in a deep reform, considering the orientation, characteristics and occupational education trend of high level and practical law talents of the JM (law), this article tries to explore the reform orientation for the JM students and then design specific ways for reform, which is a significant project to raise the training quality and distinction and meets the law master structural adjustment and social demands.
\end{abstract}

\section{Keywords-juris master; mode choice; path design}

\section{INTRODUCTION}

The law master consists of LLM, JM (law), JM (non-law) and on-the-job JM, of which, the JM (law) (hereinafter called JML) underwent a winding and discontinuous development in China: set up in 1996, suspended in 1999 and restarted in 2008. Compared to LLM, there is no a given mode to borrow for the JML, to which the student sources are mostly students majoring in law who are not admitted to LLM but agree to switch, it is little accepted by the society for its low understanding, besides, some students still have doubt about the JML when submitting an application for majors. Main problems to face currently include, first, vague understanding of the JML training goal, actually the JML is a special postgraduate degree, yet the LLM is an academic postgraduate degree. The special postgraduate degree means that it is focused on the students' professional operation in practice, however, most colleges and universities are still hovering on how to train the JML students, making no progress on how to achieve the training plan, as a result, the JML students are finalized to almost the same as other types of law postgraduate, and the training of different types of postgraduates has to go out of order or on the same way, which makes it far deviate from its original clear goal as scheduled. Second, the course teaching of JML is not different from others, and the JML courses in most colleges and universities are just repeating those taught in undergraduate education, and the experience in the undergraduate teaching is copied to the teaching of JML

"The article is one of the achievements of "Research on Case Teaching Reform of Applied Juris Master Training Mode" (Project No: 2015GXJK011) of the 2015 International \& Hong Kong, Macao \& Taiwan Cooperation Innovation Platform and Featured Innovation Project for Universities in Guangdong Province (Category of Education \& Science Research) courses. The teaching is unable to reflect the advantages of JML courses and professional skills compared to that of undergraduates majoring of law. At last, most of the professional knowledge of JML postgraduates are wide but no emphasis, professional but not essential. Within the admission category of postgraduate majors, special postgraduates are shown no difference in research orientation, it is the same with the JML. With the undergraduate courses focused on for course setting, if there are no practices in teaching, the JML with no difference in research orientation is actually not good to form a unique training mode of the JML. There are no training requirements in the research orientation distinctive for the JML in colleges and universities, besides, the courses of the JML are wide but not professional, it looks to have diverse involvements in the law field, actually it has no systematic and professional researches. In a word, the current training mode of the JML has no professional characteristics, the law vocational education is not strengthened either, which is to some degree deviating from the training goals.

\section{THOUGHTS FOR REFORM OF TRAINING MODE OF JM}

The education and teaching reform is a systematic project, to make a deep thought of and clearly understand the problems as "reasons for reform", "goals of reform" and "how to reform" has been the premise and foundation to guarantee the effect of the education and teaching reform, of which, the "goals of reform" is a guideline for the reform. [1] The law education and teaching reform is in a great situation where the country is carrying out the rule of law and promoting a unified law occupational qualification system and also a significant period for the law education and teaching reform. The training goals of JML aim at high level, special and practical law talents, stressing the practicability of law knowledge, besides, the JML setting is just depending on the employment of graduates majoring in law and social demands, whose reform orientation shall be focused on training guide, mode choice and program design.

\section{A. Training Guide to Meet Social Demands}

The law education varies with law cultures, and the law cultures of China differ from that of the West naturally, the Western law education shares a point which combines law education and occupational education, not matter what the mode is, the theory integrated to with practices to meet social 
demands of their own is an orientation that most countries insist on in the law education reform[2]. It has been a long existence for the separation of law education from law career, and the JML setting is to connect the law education to the law occupational education, aiming at training practical talents for law practical agencies. The JML is a special master, also stressing the law occupational education, yet not highlighting the occupation and application in the development as given above. The reform should be based on the social development and demands, and the social developments will reflect and embody the reform achievements. In the past years, the country has made full efforts to push the legal construction, and law talents will be needed by all fields and industries for politics and economy, besides, the establishment of legal adviser systems in government agencies also need law talents for development, which prove that a great number of practical law talents will be needed for human resource reserves, and the requirements of law service markets to law talents are being increased as well.

The JML student sources are undergraduates majoring in law who have frequently the lowest employment rate in recent years, therefore, the academic cycles and the practical fields share the opinion that the law education has been in a long term separation from the practice of law talents. For the teaching ignores the social demands in the social development, the students trained under this mode will be difficult to adapt to the practical conditions, causing a lowered expectation to students to the social demands. Though the "Training Program of Outstanding Law Talents" released earlier has pushed the law education and teaching reform, case teaching and clinical teaching have been introduced to the class of undergraduates, yet the conditions after the reform is dissatisfactory, it is not because the reform is a progressive course, the basic cause is that current reform measures fail to aim at the training goals of special master. Obviously, the JML training is required to stress the law occupational education and enable students to become practical law talents, seen impersonally, the law education is a response to the social demands. The reform measures pay little attention to the employment situation and job willingness of the JML students, showing it has been separated from the actual social demands, and no adjustment is made in time according to the supply-demand change of the law talent markets. The training goal of the JML has been made clear in the training program, what we have to do currently is to rethink of the effect of earlier reforms, and the social demands shall be based for the training mode reform. Improve the reform plans guided by the market, adjust the training modes according to social demands to achieve the sound integration between the JML quality and the occupational education market.

\section{B. Mode Choice for Occupational Education and Personalized Training}

The training mode of JML happening to be the same as that of LLM is rather a sarcasm to the law postgraduate structure than a tacit agreement on the same student sources in admission. For the JML has no a characteristic teaching of its own, so the admission to the JML is often doubtfully considered as a method for increasing income in colleges and universities, and its initial goal to adjust the law postgraduate structure is distorted. It is a necessity to select an appropriate mode for the formation of the JML training system and a requirement to separate it from other law postgraduates. The LLM is designed for academic research, and its mode choice is not based on occupational education; for the JM (non law) students receive no systematic law education as undergraduates, so the law education shall be stressed for students studying as postgraduates. By contract, in order to make the JML students different from other law postgraduates, it needs to strengthen the law occupational education and highlight the personalized training of students. At present, the JML training is in lack of occupational education and practice teaching, and it just copies the training mode of law postgraduates, over stressing theoretical learning and so called "taking undergraduate core courses to rebuild the foundation" course teaching and ignoring the personalized development of the JML. The mode choice of the JML shall make it good to introduce the law occupational education, from which, the students could make further study and acquire academic knowledge and highlight the personalized characteristics of their own, innovate individual professional knowledge and skills.

The training mode reform of the JML in the future shall follow the lead pulse guided by social demands, insist on the mode of strengthening law occupational education and highlighting personalized characteristics of majors, and gradually form a multiple JML training program, of which, to achieve the occupational education is one of the goals of deepening the law education reform, and it is a must for the JML training mode to break traditional theoretical teaching mode for transformation to practice teaching. The multiple training modes have taken into account the personalized development of the JML students, who will learn "professional knowledge" in the postgraduate period after receiving systematic law education. In addition, the personalized training mode will help students exert their subjective initiatives, participate in researches actively, explore the ways for research orientations of their own and devote themselves to the JML training. For the tutors who are always busy, the multiple training modes may be a method to reduce the tasks of tutorbased postgraduate training. So during the reform of deepening the law education teaching, we should catch the good chance to return the training of the JML to the occupational education, take into consideration theories, stress the practice, change the existing simple training mode, reduce the proportion of required courses, increase the self-learning scope, respond to the personalized development of students, and allow the JML students to select courses freely so as to strengthen the depth of professional knowledge.

\section{A High Level, Special and Practical Orientation Design Program}

No doubt that the exercises of practical skills need corresponding theoretical knowledge, otherwise, the practical operation will be lost in randomness. In fact, the law graduates are not in lack of theoretical knowledge, but what they have acquired are usually not what needed by the practical departments. As practical postgraduates, the JML students 
shall have their training programs clearly orientated and designed. The JML training program is a text to carry out the training and goals and an instructive document for specific execution of the training mode, which contain contents such as training goal, course setting, credit distribution, graduation thesis and more related directly to students' professional researches. The training program specially reflects the execution of training mode and the effect in the JML training. Therefore, with the training orientation and mode choice confirmed, the training program is a carrier to fix the reform measures and it must realize the unified orientation in the JML training.

Both the JML and the JM (non-law) are postgraduates of Juris Master, yet different in training orientation. For the JM (non-law), its special characteristics and advantages are "compound law talents", but the JML takes the "special law talents" as the special characteristics and advantages. The labor division of law service is made clear and detailed gradually; besides, the law practice itself requires special skills, and what the society needs is "special talent" but not "general talent". During the learning as postgraduates, the JML students may deepen professional knowledge of their own through specialized chance for development, and research professional knowledge and skills so as to develop the advantages of their own. Meanwhile, the knowledge and skills can be converted and related to each other, as practical postgraduates, the JML students shall have their knowledge presented via skilled operation finally, to activate the knowledge is a requirement of the skill conversion. It is well known that most of the courses that the JML students learned in the undergraduate period are theoretical ones, and teaching mode in most schools of law is a still traditional one. In the postgraduate period, when a program is designed for the students who own solid foundation in undergraduate, we should not only accept the students' personalized development, but also stress the practice teaching and professional practice exercise, which is a guarantee to further supplement practice abilities of their own. It is also an internal requirement for the JML to introduce occupational education. So based on correct major orientation, aiming at the "special" and "practical" types, consider the JML background of undergraduate education, the JML program shall reflect the social development demands and personalized research, and deepen the practice-learning system setting, so the reform of the JML training mode will be much realistic, impersonal and feasible.

\section{SPECIFIC WAYS FOR REFORM OF JM TRAINING MODE}

\section{A. Improve the Tutoring System}

One of the external environmental factors to guarantee the postgraduate education and teaching is the faculty team construction, the JML is a postgraduate education to train practical law talents, for which a dual-tutor system should be carried out, where a tutor inside the school and a tutor outside will be arranged so as to provide theories and practice-related instruction for the JML students' research. Spoken in details, the tutors inside the school generally provide theoretical teaching and few practical experience, stressing law theories knowledge to the students; the tutors outside the school are generally professionals invited by school of laws from practical agencies such as judge, lawyer, prosecutor, administrator and more, who, owning a lot of practical experience, are able to provide practical and occupational planning instruction to the students. Considering that the dualtutor system has not been widely carried out at schools of laws and the practical tutoring always goes in formalism, which causes the failure to train the JML students' practice abilities, so it is urgent to improve the tutoring system. In a new period of deepening the law education and teaching, a dual-tutor system shall be adopted for the JML students so as to strengthen the students' practical abilities and stress the law occupational education. It is an inevitable requirement for the JML education. The dual-tutor system construction shall be focused on the selection of tutors outside schools and practical instruction, of which, the selection of tutors is not a big problem, and the most important is practical instruction work system for the students by tutors. In order to guarantee the tutors selected to provide the JML students practical teaching instruction, the tutors should catch all opportunities to learn and improve themselves, namely the tutors, after completing their work, still have time and energy to instruct the JML students in practice and devote themselves to the postgraduate education in colleges and universities. As such, the JML students are guaranteed to have adequate tutors for instruction, besides, a normal and democratic assessment system shall be executed to the practical tutors to renew the tutor team resources and ensure the JML education quality, preventing the tutors from being a sleeping one. For the tutor inside schools, he or she shall be encouraged to participate in the specialty-related practical work and topic research and theoretical conversion, meanwhile, a flexible cost repayment and $R \& D$ incentive system shall be set up as the case may be.

The JML students' tutors shall have projects attracting postgraduates to participate in, otherwise, he or she will be not allowed to instruct the postgraduates. Because most postgraduates in practice are in a "herd management" condition, besides, the students have no enthusiasm in active learning, it will cost a lot of time rare for the postgraduates, acquiring nothing in knowledge but a diploma after graduation Actually the participation of postgraduates in the project research will do good to the improvement of the tutoring system, and the tutors required to instruct postgraduates should have projects shall not only have their research level raised but also the have students' academic research abilities improved. Of course, it has to rely on supporting measures for support, and the tutors and postgraduates having similar research orientation may communicate in the training.

In a word, to improve the tutoring system could guarantee the faculty for the JML education, meanwhile, stress the tutor work system setting and develop diverse occupational education modes so as to guarantee the basic and strong practice resources for the JML education. If the JML students are accepted to participate in the tutor's project, supplementary rules can be made to the tutoring system, during daily practice, the students shall be strengthened to the understanding of research orientation and the application of knowledge. 


\section{B. Explore the JML Course Teaching}

In order to increase the distinction between LLM and JM (non-law), the JML course teaching shall intensify occupational education and practice teaching, highlighting the "high level", "special" and "practical" training. The high level refers to a higher standard in professional knowledge has been acquired in the undergraduate period. The JML course teaching shall no longer take undergraduate law courses as cores, which should be reduced, and it is a must to re-learn the core courses set in the undergraduate period in order to solidify the foundations, and the foundation shall be placed in the law occupational education to avoid repeated learning or copying undergraduate courses, or the law education and teaching will be continued in theory. This is a distinction between the JML and the undergraduate courses, and the professional knowledge of the JML is not remained at a low-level understanding in the undergraduate period, and the view of professional knowledge and the wideness of professional thought are widened. The "special" refers to be skilled in academy and skills of law subject. Considering that the JML orientation differs from the "compound" of the JM (non-law), the JML course teaching may be in a less involvement in other subjects and fields, but setting specific courses for the deep researches of the JML professional knowledge. As for the professional skills, the required courses occupying a high proportion shall be changed to professional courses with characteristics of law occupational education (in practice the required course in most colleges and universities are basic course, yet the course are generally core course set in the undergraduate period), such as law occupation standards and ethic, legal instruments, legal negotiation, legal methods and more. The courses are all set at Fudan Training Program and China University of Political Science and Law Training Program, yet having a not high credit proportion. The "practical" refers to be good at practical operation and rich in practical experience, which is a key distinction between the JML, undergraduate majoring in law, and LLM. In order to raise the JML professional practice level and highlight the practical teaching, the JML course teaching shall stress the practice teaching, emphasize the connection between theory and practice and take practical law theme and law occupational course as main trunk courses. The practical courses can be taught by selected tutors, and the theory course teaching may adopt case teaching, seminar-style teaching and more.

Therefore, in order to introduce a JML-based featured course teaching, it is necessary to make improvement on the course setting in the existing training mode, aiming at the "high level and practical" training orientation. The required courses (core parts for undergraduate) stipulated in the Training Guideline Program disagree with the law occupational education, which should be modified. The JML students have received a four-year systematic basic law knowledge education in the undergraduate period, who should as postgraduates further upgrade law knowledge, deepen professional training, strengthen occupational skill exercise, and the course teaching shall properly promote practical teaching modes[3]. And it is necessary to make a material improvement in the course setting reform.

In summary, the course teaching is closely related to the JML professional knowledge confirmation, professional practice thought deepening and more, and its course teaching should stress the law occupational education and train students' professional operation skills via practice teaching and practice ability assessment

\section{Build a Professional Development Mechanism to Distinguish the Research Orientation}

Regardless the general education or vocational education, the difference between special master and academic master lies in the research orientation. The JML is a special master, which has been not distinguished in the research orientation since its setting, nor does the Training Guideline Program gives opinions for it. The JML has its research orientation confirmed at the time of application, and the courses are only the required for the subject, and its view is much wide for students who, compared to the undergraduate, may learn more knowledge of level II law. Though the JML has more abundant courses, yet in order to train special law talents, the JML training must be specialized and gradually close to the training goal and occupational demand. With the JML course teaching improved, to build a professional development mechanism to distinguish the research orientation will be an extended course reform. If having no specialized development, the JML will have personalized training feature and have to be the same as the teaching of undergraduates majoring in law and JM (non-law). In the opinion of the author, before admission, the JML students shall select tutors related to their interests and make preparation for the academic research shared by their tutors. It may change the phenomenon that tutors offer instructions only when students write the graduation thesis, and that the JML students confirm at the term beginning the major research orientation makes no difference from the graduation thesis orientation is a precondition to distinguish the research orientation development mechanism.

The course setting stated in the Training Guideline Program is based on the grade I of the law, in order to distinguish the research orientation development mechanism, we have to reject the improper mode and turn to the course setting on the basis of major orientation. The schooling period of the JML is two years, and the first year shall be focused on class teaching, where the major development mechanism to distinguish the research orientation shall make a breakthrough. The major-based required courses shall not be core ones in the undergraduate period, according to the LLM course setting, students will select the courses as per the research orientation of their own, only the JML courses is stressed on the practical project study. The Training Guideline Program has no feature of specialization, the Chongqing University Training Program adopts a creative specialized training mode, in addition to the core courses in the undergraduate period as required course, it also points out that the JM students may decide on the major orientation of their own according to the elective courses and practical courses (within total credit) special for the major and the completed gradation thesis. It is noted that with the instruction of tutors to the major research orientation, the JML students, after deciding on elective courses and graduation thesis, may form the academic research orientation and abilities of their own so as to raise the professional competitiveness, which is a measure that can be promoted for 
the reform of the JML training mode. Based on which we can suppose that the course learning will replace some required courses with more elective courses, it will help the JML students to find a personalized major courses with higher feasibility, and prevent the so-called core courses from becoming stiff course in a high proportion, or the academic cycles and the practice field criticize the JML only a repeated learning, and a second undergraduate education.

On the other hand, in order to exert the major development mechanism to distinguish the research orientation, the training program of postgraduates is also crucial. A "individual training program" is set in the postgraduate management system in some colleges and universities, yet most of which are made in formalism, and teachers give no detailed instruction to postgraduates to understand major course and training programs so as to achieve the individual program. In order to build a major development mechanism to distinguish the research orientation, it needs to value the individual training programs so as to push the JML education toward a specialized development and individual academic research, and the knowledge will be not only wide but also essential, showing an individualized training mode.

To optimize the law education and teaching and strengthen the law occupational education is a trend for the law teaching reform, and the JML training mode has been unable to adapt to the law occupational education or meet the social demands, even some training contents go against the JML at the time of setting, and its reform must begin with faculty team, course teaching, major research and more so as to form a specialized JML training mode and increase its acceptance by the society and undergraduates majoring in law through the reform.

\section{CONCLUSION}

The co-existence of LLM, JM (non-law), on-the-job master and the repeated JML forms current structure of postgraduates of laws, in fact, the JML training is inadequate in experience, and the existing training modes are always unable to meet the goal of major setting, showing no major advantages or study value. In the face of the situation where high quality law talents are needed on law service markets and the promotion of legal construction, we have to admit the necessity and active role of the JML, yet its training mode must be rebuilt. The same as the reform of other fields, the law education and teaching reform must be made clear in the reform orientation in order to make achievements in the JML training mode reform. The reform having no orientations will be difficult to explore a specific way applicable for the JML reform. Aiming at the problems disclosed in the JML training mode, the training mode reform shall return to the major feature of the JML, and integrate the "special" and "practical" to the training mode and re-shape the JML training features. To some degree the teaching is a response to the social industrial demands, so the reform shall follow the actual conditions of social development and demands and adjust the JML training program as the case may be. The specific ways for reform is an impersonal reflection of the reform orientation, in order to really shape the training features the JML owns uniquely, the reform in the course setting, tutoring system and major development must reflect professional features of specialization and practice teaching of the JML. The reform of the JML training mode is a progressive course, and it is unavoidable to have a vague understanding of the JML, a new thing, and non-different training, however, no matter how the reform is done, the main line is still kept unchanged to highlight the JML major feature and advantages in practice and keep it distinguished from other types of postgraduates of laws.

\section{NOTES}

The training programs are mainly applicable for undergraduates majoring in law, data source: school of laws in colleges and universities or school of postgraduates websites (graduate school of China University of Political Science and Law: http://yjsy.cupl.edu.cn/; Fudan University Law School: http://www.law.fudan.edu.cn/; Soochow University School of Law, http://law.suda.edu.cn/) and National JM Education Steering Committee (http://www.china-jm.org/). Data ending on Aug 6, 2016, inclusive of a possibility that the training programs in some colleges and universities are in revision.

\section{REFERENCES}

[1] Huang Yunping, Jiang Minghua, Xiao Naitao, Direction and Ways for Education and Teaching Reform in Local Universities [J]. Research in Higher Education of Engineering, 2010, (5): 102-103.

[2] Yin Chao, Comparative Research on Law Education within the Scope of Law Culture-A Case Study in Germany, Japan, the UK and the USA [M]. Beijing: China University of Political Science and Law Press, 2012: 272.

[3] Mo Hua, He Huiying, Thoughts of Education Dilemma in Juris Master (Law) [J]. Work \& Study Abroad, 2010 (16): 79. 